\title{
Provincial Monitoring and Control System in Vietnam: Case Study of Hai Duong Province
}

\author{
Pham Duc Binh ${ }^{1}$ \\ ${ }^{1}$ University of Hai Duong, Hai Duong, Vietnam \\ Correspondence: Pham Duc Binh, University of Hai Duong, Hai Duong, Vietnam. Tel: 84-912-026-827. E-mail: \\ phamducbinhnhien@yahoo.com.vn
}

Received: February 20, 2014

Accepted: March 13, 2014

Online Published: March 25, 2014

doi:10.5539/ijef.v6n4p220

URL: http://dx.doi.org/10.5539/ijef.v6n4p220

\begin{abstract}
The objective of this paper is to analyze the provincial monitoring and control system in Vietnam. Through the case study of Hai Duong Province, the research results have shown that monitoring and control activities in this province have been carrying out in a fairly synchronous, comprehensive manner. In general, through monitoring and control activities, the functional agencies have handled some weaknesses concerning the organization and implementation of government administrative apparatus at the provincial level, but also the negative and corruptive acts of State officers, the duplications and overlaps activities among governmental and relating agencies and organizations. On the basis of these obtained results, we have proposed some relevant recommendations for the Vietnam government and its provincial management units.
\end{abstract}

Keywords: provincial monitoring and control system, Hai Duong, Vietnam

\section{Introduction}

Monitoring and control constitute an essential function of State management, including management at provincial level. Monitoring and control activities make important contributions by strengthening the performance of the State management, by improving the law, legal system, and by guaranteeing citizens' legal rights. In the context of regional and international integration and globalization, great importance is accorded to the role played by the State in monitoring and control activities, especially in localities. In Vietnam, particularly in Hai Duong Province, the provincial monitoring and control system is developing by obtaining some initial achievements. However, there still exist shortcomings in this provincial system that has caused many socio-economic consequences, particularly to enterprises, and even to the monitoring and control agencies and related organizations themselves.

In this context, this paper focuses on analyzing the provincial monitoring and control system of Hai Duong Province in Vietnam. The research objectives involve: (1) the actual situation of the provincial monitoring and control system in Vietnam through a case study of Hai Duong Province during the period of 2010-2013; and (2) by proposing some recommendations for improving the performance of this system. The paper is organized in four sections including theoretical background, methodology, research results and finally some proposed recommendations.

\section{Theoretical Background on the Provincial Monitoring and Control System in Vietnam}

Monitoring and control activities are an indispensable function in the State management, including the one at the provincial level. These activities make important contributions by improving the performance of the State management in general and by reforming the administrative system of the State in particular. In Vietnam, the monitoring and control activities are organized on the basis of the assignment among the three powers: legislative, executive and judicial ones (The Constitution of the Socialist Republic of Vietnam, 2013), in which the National Assembly is the sole organization having the constitution power, legislative power and the one of carrying out the supervision over all operations of the State. Government is defined as the top administrative unit of the State, as an executive unit of the National Assembly, headed by Prime Minister. Legislative organizations include the system of Courts with the trial functions and the People's Procuracy with the function of supervising the compliance with the law of State organizations, State staffs, and citizens. The State government apparatus in localities is attached with the formation of People's Councils elected by locals and the members of People's 
Committee who are elected by People's Councils.

In the opinion of the Vietnamese government, the monitoring and control activities constitute (1) the ways of realizing the leadership of the Socialist Party and the State, (2) the ways realizing the people's democratic rights, and (3) the important factor for enforcing the law, uncovering, preventing and treating the acts of violating the law. Activities of monitoring and control constitute an integral part of the system of the State organizations, from the Central to the local levels. The setup of the Special Inspectorate in 1945 in Vietnam was the initial step for the formation of the actual monitoring and control system.

In addition, the organization and control activities of the units of the Socialist Party of Vietnam play also an important role. This is one of the specific aspects of the Vietnam political system based on the principle that the Socialist Party of Vietnam is leader. The Party's activities of monitoring and control are always closely associated with activities of monitoring and control of State units. The monitoring and control system of the State at all levels was formed and ensure the correct leadership of the Party towards the activities of the State government apparatus. This system at provincial level in Vietnam is characterized by the following aspects:

- The provincial monitoring and control activities is a component of the uniform system from the Central to the local levels: As prescribed by the current law, the Vietnamese administrative units are divided into province and city levels directly under the Central Government; provinces divided into district, township and city level directly under provincial administration; cities directly under the Central Government divided into rural, urban district levels; districts divided into commune, towns levels; cities and townships directly under provincial administration divided into ward and commune levels; urban districts divided into ward level. According to the law, the State administration in localities is mainly realized by the People's Councils, People's Committees and departments and sections directly under People's Committees.

- The provincial monitoring and control activities must comply with the State management principles: The first principle is democratic concentration and obeying of the Central Government. So, the organization and realization of provincial monitoring and control activities must comply with the State management principle that: the Party is leader; the people participate in management; observing the law and strengthening legal system; democratic concentration; combination of sectorial management with local and territorial management. The second principle is the uniform powers of the State with the assignment and close coordination among the three legislative, executive and judicial powers. In State government apparatus of Vietnam in general and the one of provinces in particular, there is not any units that can hold an entire power branch of the State. Activities of each unit lie within the relationship with activities of other, under the monitoring and supervision of social agencies or organizations and citizens.

- The provincial monitoring and control activities serve the administrative management function of the State in localities: Management at provincial level carries out the function mainly for administrative and economic management of the State in localities. Meanwhile, every activity of State administrative units is subject to the control by superior State units, by social organizations and citizens in order to ensure the legal system in State administrative management.

- Each provincial monitoring and control unit carries out a function in a uniform system: Each type of State unit at provincial level is set up to carry out certain functions. The State set up agencies, organizations in charge of carrying out the monitoring and inspecting functions include courts, procuracy, inspectorate at provincial level. The inspecting, monitoring, supervising activities involve different contents, natures, targets, procedures for carrying out, but in coordination with each other for strengthening the legal system and order.

\section{Methodology}

In order to study the actual monitoring and control activities at provincial level in Vietnam, we have conducted a research of theses ones in Hai Duong Province during the period of 2010-2013. The following two research methods were applied:

The first focused on studying, analyzing and summarizing the documents, legal documents on monitoring and control, reports of 2010-2013 of the State units in Hai Duong Province such as Customs Branch, Market Management Branch, State Treasury, Inspectorate of the province and People's Tribunal.

The second method focused on interviewing several leaders and officers working at monitoring and control agencies in Hai Duong province such as the provincial People's Committee, People's Tribunal. So, 20 agencies and organizations in the province were involved in our interviews. 


\section{Research Results}

Through the analysis of the actual monitoring and control activities in Hai Duong Province during the period of 2010-2013, we have pointed out the achievements and shortcomings in these activities of this province. The main research results are as follows:

\section{Firstly, concerning the monitoring and control activities of the Socialist Party, social organizations and citizens in Hai Duong Province.}

The agency that exercises the monitoring and control rights of the Socialist Party in Hai Duong Province is the provincial Party Committee Congress, the Standing Committee of the provincial Party Committee Conference, Control Committee of the provincial Party Committee and the subordinate Party organizations. According to the report on summing up the monitoring and control activities of the Control Committee of the provincial Party Committee in 2013, control was conducted by Party Committee at all levels with 1,710 Party members and 1,606 subordinate organizations of the Party; of which 33 subordinate Party organizations and 177 Party members were found with signs of violation. During the year, the Party Committee, Control Committees at all levels reviewed, decided to impose discipline on 407 party members violating the Party regulations (Phan, 2012). From that, the Party organizations within the Party Committee had better management of their members and at the same time found out inadequacies that should be adjusted, supplemented. However, there still remained some shortcomings such as: some Party Committees and control committees were not active, proactive in inspecting party members and party organizations when there were signs of violation; still slow in inspecting, supervising and assisting the Party Committee in inspecting under program; the quality of several controls, supervisions was still limited. There still remained cases in which the party members were not timely and seriously reviewed, dealt with; still slow in handling denouncements.

The supervision activities of by social organizations and citizens in the province were reflected through activities of People's Inspectorates. As result of summing up these activities during the 2011-2013 period of the People's Inspectorates in Hai Duong Province, there were 5,544 cases (21 cases/people's inspectorate on average) that were founded and petitioned to the competent authorities and functional bodies; 5,150 cases $(92.89 \%)$ were reviewed, handled by the competent administrations and functional organizations at all levels. Among the cases handled by the administrations at all levels, 1,344 cases involved the land violation; $45,035.7 \mathrm{~m}^{2}$ of land was petitioned for handling, recovering for organizations and individuals; 237 cases involved the economic issues, with over 1,910.2 million dong was recovered; 1,121 cases involved in security and order; 1,017 socio-cultural cases and 1,431 cases in other fields. Members of People's Inspectorates of communes, wards, towns also took active part in activities of assisting in legal affairs, acting as members of grassroots reconciliation teams and succeeded in reconciling 3,356 cases of internal contradictions of the people, thus helping improve the performance of reconciliation at grassroots level, the settlement of disputes, contradictions arising in residential areas (Hai Duong People's Inspectorates, 2013). Nevertheless, in some places, the people elected inspectorates on their own, which operate not under provisions of the law. In many other places, people's inspectorates exist only in form, even their names do not conform to the function, duties assumed, very easily mistaken with the inspectoral functions of power agencies, organizations.

\section{Secondly, concerning the organization and activities of public authorities of Hai Duong Province.}

The organization and activities of public authorities of Hai Duong Province involve provincial People's Council and People's Committee, People's Tribunal, People's Procuracy and agencies, State Inspectorate.

The provincial People's Council supervises activities of the Standing Committee of the provincial People's Council, People's Committee, People's Tribunal, People's Procuracy. Also it supervises the law compliance by State units, socio-economic organizations, people's armed forces and citizens in localities. The structure of the provincial People's Council of Hai Duong comprises three sections including Economic and Budget Section, Legal Section and Socio-Economic Section. Periodically, the province People's Committee meetings are held at least twice a year in June and December. As from 2000 up to now, at each the provincial People's Committee meeting, Chairman of the People's Committee, directors of departments, sections are requested to answer inquiries of delegates of the provincial People's Committee and of voters as well. However, apart from the inquiries and answers that met the requirements, with concurrence of voters and delegates of the People's Committee, these activities still remain several spare and superficial opinions. A lot of delegates have regard, hesitation; inquiries are still concentrated on some certain delegates; some agencies answer inquiries with the contents inconsiderately prepared, tending to tell achievements, not going directly to the core or blaming for objective reasons. Worse still, some people try to avoid, shuffle off responsibility upon others; post-inquiry supervision and way of influencing the questioned ones are still passive. That was why for the many pressing 
issues of the people as raised by delegates at previous meetings of the People's Committee have not been actively handled, but even falling into oblivion.

The actual situation of the supplying of documents, information to People's Committees at all levels in general and to People's Committee delegates in particular at present cannot ensure the performance of supervision activities, specifically: People's Committee delegates are delivered reports by the Standing Committee of the People's Councils, People's Committees at the same level and other documents concerning activities of People's Council 5 days at the latest prior to the date of opening People's Council's meeting; the Standing Committee of People's Council deliver to People's Council delegates draft resolutions, reports, plans to submit to the People's Committee, report on appraisal by boards or sections of the People's Committee and other necessary documents. In reality, there still remain restrictions in the implementation thereof, every year delegates are delivered documents when the two meetings are held only; whereas most legal documents, codes of the National Assembly, the Government, ministries, and decisions by People's Committees are not copied and delivered to delegates. Hence, when monitoring activities by agencies, organizations and lacking legal documents and actual information, delegates will have no grounds for checking, comparing and as a result they'll be passive in proposing their opinions or their opinions will be undeep, only relying on their own knowledge, no grounds for judgment.

Appraisal of work reports by agencies as assigned by the Standing Committee of the People's Committee, assistance of the provincial People's Council in supervising activities by local organizations, individuals. At present, Article 36 of the Regulations on Operations by People's Councils at all levels 2005 supplies guidance for boards, sections on appraisal, yet this is still too simple and unspecific. Particularly, at the moment, when reports, as those of the Courts and Procuracies for example, focus usually on description of data and information in general terms but with very few analyses of the causes and the real situation of offences occurring in the province. This has resulted in the low quality of the appraisal reports made by sections of the People's Committee. The contents of the same are still dwelt on expressions, style and figures. The reasons for supplementing, changing a number of contents compared with the reported as planned are not persuasive. The most important content, that involves the analysis of provincial plans or policies by comparing with the actual real situation in Province is accorded few attention.

Actually, it is not clearly stipulated in the current law concerning the standards, conditions to be a provincial People's Council delegate. Most of them are State officers, office-holders and multi-office holders. In fact, this organization of People's Committee delegates being office-holders are unreasonable, because the delegates need more time to carry out the tasks of a People's Committee delegate and at the same time the ones of an officer, an office-holder. Furthermore, they are the subjects to exercise the monitoring and control rights; and also they are the objects under the supervision, inquiries of their leaders or direct superior State units. So, this does not guarantee the objectivity and proactivity in the monitoring and control activities of the provincial People's Council.

People's Procuracy of Hai Duong Province operates under the provisions of Law on the Organization of People's Procuracies. According to the report on summing up activities of the People's Procuracy of Hai Duong Province, in 2013, there are 1,082 uncovered cases, 50 cases less than that in the same period of the previous year. And concerning the civil affairs such as marriage and family, there are 3,419 handled cases, so an increase of 19 cases. In civil law enforcement, 8,020 among the total of 10,333 cases were carried out. The provincial control branch performed well public prosecution practices and control of judicial activities in the criminal field such as (1) handling denouncements, information about crimes, (2) controlling the arrests, detentions, holding in custody; (3) exercising the public prosecution and control of criminal cases; (4) controlling the trials; (5) handling the letters of claims, denouncements in the judicial field. The provincial control branch however still shows shortcomings in its work such as the management, classification, holding denouncements, information about crimes that were not well done at some units; the processing was slow, with poor quality of control and investigation; in some cases supplementary investigation was returned. The situation of land disputes tends to increase, in a complicated manner throughout the country in general and in Hai Duong Province in particular. The cause of this is due to the system of laws, policies of the State on land at each historical period is unstable, incomplete, not keeping up with the market mechanism. Also, most of the people, particularly in rural areas, have limited awareness of the law; they think that land is left by their parents, grandparents, ancestors; so it's their own property. Whereas, with the urbanization process at high speed, the emergence of numerous new urban areas, road building and other projects, demand for use of land increases by pushing the land price up high; so disputes arise among the parties involved in land transfer and then are brought to Courts for settlement. Disputes in localities concern mainly: land use rights, land use right transfer contracts, land use right gifting contracts, land 
use right inheritance. In fact, during the course of handling civil law cases incidental to disputes over land in Hai Duong Province, there occurred so many difficulties, inquiries, with a lot points of view diverging when applying provisions of the law.

The monitoring and control activities of the People's Tribunal of Hai Duong Province involve the inspection of the legality in administrative decisions and administrative acts by the agencies, individuals in the positions related to the cases being tried by the Courts. According to the report in 2010, the People's Tribunal of Hai Duong Province treated 3,347 among the 3,409 cases handled, accounting for $98.2 \%$, of which $99 \%$ were the criminal settlement, $97.8 \%$ were the civil affairs. Compared with that of 2009 , the number of cases handled increased by 52 , the number of cases settled increased by 81 . There were no cases in which the innocent was unjustly tried or the guilty was omitted. The rate of judgments, decisions cancelled due to faults of judges: $0.79 \%$ (lower than 2009, 0.24\%); the rate of judgments amended due to faults of judges: $1.2 \%$, these were all lower than the rate prescribed by the branch. The Courts at two levels took the initiative in coordinating with public security, procuracy in settling in a timely, strict and clear manner dozens of key lawsuits that were complicated and of great social concern; organizing roving trials of 180 cases (increased by 40 against that of 2009) (People's Council of Hai Duong, 2013). The criminal law enforcement, control of judgments, decisions in force by district People's Tribunals and settlement of claims, denouncements in juridical terms achieved good results.

The State control system of Hai Duong Province comprises provincial Inspectorate, sectorial grassroots and district control organizations. With 3,027 controls conducted from 2005 till 2012, the provincial Inspectorate achieved high results in special subject and on a large scale under the guideline of the Government Inspectorate on the management and use of land, the collection and use of social insurance, as well as the control of the Plan for Solidification of Schools, Classes and Teachers' Offices. Through the monitoring and control activities, there are economic violations of 162.3 billion dong; 59.1 billion dong was petitioned to be recovered to the State Budget; 102.3 thousand $\mathrm{m}^{2}$ of land; cancellation of non-purpose expenditure, removal from final settlement value and proposing the competent authorities to consider and handle 90.8 billion dong; proposing to handle other 13.2 billion dong; proposing to impose administrative discipline on one collective and 178 individuals; transferring to investigation agencies 4 cases (People's Council of Hai Duong, 2013).

Dealing with the people, solving claims, denouncements were also attached importance to by the monitoring and control system of Hai Duong Province. Steps of verifying, appraising were reviewed, dealt with in a close, open, democratic manner, along with numerous contacts and dialogues with citizens by reducing the weaknesses, shortcomings throughout the settlement process. Through settlement of claims, denouncements, petitions were filed for the recovery and payment to the State Budget over 2.3 billion dong; the recovery and treatment of 66 thousand $\mathrm{m}^{2}$ of land; petitions for imposing administrative discipline on 10 collectives and 234 individuals; transfer of documents to public security agencies concerning 13 cases (People's Council of Hai Duong, 2013). Controls all achieved certain results, with violations detected to be petitioned for timely remedied and treated, so as to reduce availing of negligence in management to commit corruption. However, these activities in Hai Duong Province revealed the duplications and overlaps in carrying out the duties among agencies, State inspectorates in localities and activities of Party control, supervision agencies of provinces. No performance was achieved in receiving, handling, managing, monitoring and supervising claims, denouncements; some cases had to be dealt with for many times, through different levels but to no avail. The "petition" approach of inspectorates did not represent State powers. Officers, inspectors were sparsely scattered; their legal positions were not clearly defined neither.

\section{Thirdly, concerning the organization and activities of departments, sections, branches in Hai Duong Province.}

Investigating deeply the monitoring and control activities of the specialist inspectorates in Hai Duong Province has shown that in legal documents, particularly in the field of road, waterway safety and order, there still remain the duplications and overlaps between traffic police and traffic inspectorate. On the other hand, due to the irresponsibility of officers, office-holders in this field, activities of checking, inspecting, preventing have not been accorded a right attention. This results the increasing traffic accidents in the Province. Further, though traffic inspectorate is the specialist one, but it does not belong to the State inspectorate system. The too sparsely scattered inspectorate system results in the fact that the lengthwise management and control of the State agencies depend mainly on the management and control of the State management units at the same level.

In the People's Public Security forces, the delineation is fairly distinctive between Investigation Police in accordance with the Code of Civil Procedure and the Ordinance on Criminal Investigation in relation with socio-economic controls, dealing with claims, denouncements. However, the contents are overlapped by 
focusing on the activities of economic police, economic security forces and State control agencies, organizations of the province. In many areas, these were left vacant, loose like in the field of preventing trade frauds, external economy, and programs for cooperation with foreign partners.

The actual financial control of Hai Duong comprises Inspectorate of the Financial Department, Control and Treatment Division of the Tax Branch, Inspectorate of Branch of Treasury and Inspectorate of Branch of Customs. In general, the financial monitoring and control activities have been achieved some significant results. In particular, the manner of monitoring and control of agencies consist to concentrate, distribute and use the financial resources. In recent time, the control agencies in Hai Duong uncovered several violations committed by numerous organizations and individuals by handling and evicting billions of dong each year to the State Budget. At the same time, after monitoring and control, they petitioned to the financial sector, the Government to timely rectify gaps in the policies, regimes of income-expenditure, and payment to the State Budget. Apart from the results above, the financial agencies in Hai Duong Province revealed some following weaknesses: (1) its organization fails to meet the income-expenditure task requirements in the current period and in time to come; (2) improper staff arrangement; (3) taxation, treasury officers somewhere do not meet the assigned work requirements. Somewhere, the combination between the financial department and the People's Committees is not enough strong, particularly at the commune, ward, district and city levels. The income-expenditure procedures are not summed up for reviewing and disseminating. Especially, the big problem at present is the overlaps of functions, targets and organization of monitoring and control activities, particularly in the field of finance. Particularly, there is the overlapping relationship between inspectorate of the finance department and State audit organization; and the relationship between agencies of the financial department and other monitoring amd control agencies.

\section{Recommendations}

Based on the research results presented above, we propose some recommendations for completing the monitoring and control system in Hai Duong Province. These recommendations are divided into two main groups as follows:

\subsection{Recommendations for the State}

Firstly, completing the provisions of the law on the supervisory functions of People's Councils: Concerning the reporting process, in order to assist more efficiently provincial People's Council, the information about State units' activities must be correct. Also, in order to heighten the responsibility of such units to People's Council, the law should stipulate three reporting rules: annual report at People's Council meeting; monthly, quarterly reports at People's Council. If there is no provincial People's Council meeting, the report is made by the request of provincial People's Council or the Standing Committee of provincial People's Council when political, socio-economic events have important impact on the social life.

With regard to inquiries of delegates of the People's Council: the law should stipulate the framework for People's Council to issue resolutions on answering inquiries and the responsibility of the interviewed ones. With regard to detailed monitoring and control measures, the law should stipulate specific measures for solving the post-meeting inquiry matters such as who have the power to review such settlement, how to carry out, the responsibility of the questioned one when failing to carry out what one has promised.

The government should issue documents with guidance on framework, procedures for taking legal measures under the rights of provincial People's Council. It should break down responsibility and measures, sanctions in detail and respective to the extent of offences. Also, it should break down responsibility and measures, sanctions based on the extent of violation of offenders; and the law should stipulate slighter forms of treatment such as expostulation, warning.

The law should also stipulate clearly procedures, scope of supervision, legal value of supervisory conclusions.

Secondly, completing legal documents to delineate more clearly the dividing line between functions and duties, and reshuffling of agencies, organizations such as State audit, financial inspectorate and State inspectorate. The law should stipulate the clear rules for the inspectorates of the central financial agencies in Province.

Thirdly, improving the procedures for formulating legal documents on monitoring and control: Monitoring and control activities should take the positive factors, the common things in reality as standards for analyzing, checking the problematic contents in the law. From that the monitoring and control agencies can propose recommendation for repealing or amendment, supplementation and completion so as to timely eliminate the obstacles and promote the economic development.

Fourthly, strengthening the role played by Administrative Court: The government should improve the quality of 
information for administrative courts. It should extend the controls and trials of the validity of socio-economic activities.

\subsection{Recommendations for Provincial Management Agencies}

Firstly, strengthening the relationship between People's Council and agencies, organizations, people in localities: The relation between People's Council and the Party Committee and agencies of provincial Party Committee: One of the important contents concerns the organization of human resources. The Party Committee at different levels should have plans of training, fostering and recommending the elite party members who are virtuous, talented for the key position at People's Council;

In the relation between People's Council and Vietnam Fatherland Front, members of the Front, provincial People's Council should have a close coordination with the Fatherland Front and social organizations in the province to carry out the monitoring and control activates in the compliance with the Constitution and the law, particularly the struggle against corruption in the government administration apparatus;

Concerning the relations between provincial People's Council and voters: This relation should be strengthened. It should increase the minimal number of times meeting with voters of provincial People's Council by specifying clearly and in detail each time contacting voters. To make it easy for voters to contact delegates and to reflect the stinging issues of their life, the information about identity of delegates of People's Council should be disclosed.

Secondly, further strengthening the relation and coordination in monitoring and control activities between the Party organization and People's Council and People's Committee of province, State inspectorate: People's Council, People's Committee have responsibility to make every condition for the monitoring, supervision by the Party Committee have quality and practical performance. There should be a process for coordinating effectively between monitoring and control activities the Party and the ones of the State Inspectorate, particularly in dealing with denouncements. There should be more strict adjustment and coordination in terms of activities of monitoring and control organizations and agencies.

Thirdly, minimizing the duplication and overlaps in activities of monitoring and control activities of agencies and organizations in localities: That should be implemented by assigning the provincial Inspectorate to sum up, handle and submit to provincial People's Committee for approving the programs, monitoring and control plans in charge of all monitoring and control agencies and organizations in the localities. At the same time, these one should take an active role by requesting the Central Government to permit redetermination of the functions, duties of each provincial control, monitoring agency, organization, particularly in the economic and financial aspect.

Fourthly, improving the quality of monitoring and control staffs: The Province should carry out regular refresher training through Conferences to sum up and review in combination with short-term refresher training in deep profession management operations. Also, it should reform preferential policies on salary, allowances for officers, office-holders. Then, the Province need to invest and equip for State inspectors and supervisors the necessary working conditions such as transport, tools for carrying out the duties such as cameras, sound recorders, computers, etc.

Fifthly, for each agency: The Province should carry out financial piecework in order to improve the performance of monitoring and control activities by eliminating the redundant procedures, thus helping formulate legal documents in a closer and more simple manner. Also, it should disclose the financial situation by permitting the people to involve in the supervision over financial income-expenditure.

\section{Conclusion}

On the basis of analyses of the provincial monitoring and control system in Vietnam, particularly the case study of Hai Duong Province, the paper has summed up and pointed out the successes and shortcomings in the monitoring and control system of Hai Duong Province. The research results have shown that monitoring and control activities in Hai Duong Province have been carrying out in a fairly synchronous, comprehensive manner. In general, through monitoring and control activities, the functional agencies have uncovered, handled some shortcomings, weaknesses concerning the organization and implementation of government administrative apparatus at the provincial level, but also the negative and corruptive acts of State officers. However, monitoring and control activities implemented by agencies of the Socialist Party and the State in Hai Duong Province still reveal limitations. They do not meet the pressing requirements of renovation process of the country, particularly on the front against corruption, thrift, against smuggling and wastage. On the other hand, the duplications and overlaps activities still occur among governmental and relating agencies and organizations in the Province.

On the basis of the analysis of the monitoring and control system in Hai Duong Province, we have proposed 
several recommendations for the State and provincial management units. With such outcomes, the paper is intended to clarify the role of the provincial monitoring and control system in Vietnam by identifying and analyzing the shortcomings and its causes; from that by proposing recommendation for improving the performance of this provincial system in Vietnam.

\section{References}

General Statistics Office. (2012). Statistical yearbook of Vietnam 2012. Statistical Publishing House, Hanoi.

Hai Duong People's Inspectorates. (2011-2013). Annual activities reports 2011-2013 of Hai Duong People's Inspectorates. Hai Duong People's Inspectorates.

People's Council of Hai Duong. (2011-2013). Annual activities reports of People's Council of Hai Duong 20112013. People's Council of Hai Duong.

Pham, N. A. (2000). Finance monitoring. Hanoi: Finance Edition.

Phạm, V. N. (2010). The monitoring and control system at provincial level in Vietnam. Statistical Publishing House, Hanoi.

Phan, T. L. H. (2012). Reforming the local government system in Vietnam-District or Commune Level? Hanoi Law University.

Standing Committee of the National Assembly. (1990). Inspection Ordinance-1990. Statistical Publishing House, Hanoi.

\section{Copyrights}

Copyright for this article is retained by the author(s), with first publication rights granted to the journal.

This is an open-access article distributed under the terms and conditions of the Creative Commons Attribution license (http://creativecommons.org/licenses/by/3.0/). 